\title{
Efficacy And Safety of Combination of Tamsulosin with Solifenacin And Tamsulosin Alone In Treatment of Double-J Stent Related Lower Urinary Tract Symptoms: A Randomized Clinical Trial
}

\author{
Shah $\mathrm{Rs}^{1}$, Agrawal $\mathrm{Cs}^{1}$, Agrawal $\mathrm{S}^{2}$,Singh $\mathrm{Sk}^{1}$, Thapa $\mathrm{N}^{1}$ \\ ${ }^{I}$ Department Of Urology, B. P. Koirala Institute Of Health Sciences, Dharan, Nepal \\ ${ }^{2}$ Department Of Dermatology And Venerology, B.P. Koirala Institute Of Health Sciences, Dharan, Nepal
}

\begin{abstract}
Purpose: To compare the efficacy and safety of combination of Tamsulosin and Solifenacin with Tamsulosin alone in improving the lower urinary tract symptoms of patients with indwelling double-J ureteral stents (DJS). Materials and Methods: A total of 70 patients with DJS were randomly divided into 2 groups. In group I $(n=$ 35), all patients received combination of both tamsulosin $0.4 \mathrm{mg}$ and solifenacin $10 \mathrm{mg}$ daily and in group II $(n=35)$ all patients received tamsulosin $0.4 \mathrm{mg}$ daily. All patients completed the International Prostate Symptom Score (IPSS), quality of life component of the IPSS (IPSS/Qol) and Visual Analogue Pain Scale (VAPS) questionnaire, before insertion, at $3^{\text {rd }}$ day of stenting and at 2 weeks after stenting. Urine for Routine and microscopic examination and culture and sensitivity were sent on $3^{\text {rd }}$ postoperative day or before the discharge of patient and sexual discomfort was assessed after 2 weeks of stent insertion.

Results: The demographics and preoperative questionnaires scores of both the groups were comparable. There were statistically significant differences in all scores in favor of groups I as compared to group II. Group I showed statistically significant differences in total IPSS with P value $<0.001$, QoL score with $P$ value $<0.001$, and VAPS score with $P$ value $<0.001$. Patients were also evaluated after 2 weeks for sexual discomfort and found $4(15.4 \%)$ patients with tamsulosin and solifenacin had discomfort whereas 22 (84.6\%) patients receiving tamsulosin had discomfort which was statistically significant ( $P$ value $<0.001)$.

Conclusions: Combined therapy of tamsulosin and solifenacin significantly alleviated lower urinary symptoms associated with double-J stents as compared to tamsulosin alone.
\end{abstract}

Keywords: Double-J stent, UTI, IPSS, QoL, VAPS

\section{Introduction}

Ureteral stents, which were introduced by Zimskind et al in 1967, are widely used for urinary tract disease (Zimskind1967). These are routinely used to resolve ureteral obstruction caused by various etiologies. The double-J stent, which is the most common form of ureteral stent, is used in ureteral obstruction, obstructive pyelonephritis, intolerable acute renal colic, ureteral edema, ureter perforation following endoscopic procedures, and diseases such as steinstrasse (Chew and Denstedt, 2004; Jeongand Lee, 2004). Despite the usefulness of double-J stent, some of the patients might encounter stent-related morbidities such as urinary tract infection (UTI), lower urinary tract symptoms (LUTS), stent-related body pain, and hematuria. These symptoms represent a prevalent problem with considerable effects on the quality of life, substantial general health, work performance, and sexual matters in both genders. (Joshi et al, 2001; Joshi et al, 2003; Sighinolfi et al, 2007). The morbidity associated with ureteral stents is well documented. Particularly general health, sexual activity (Sighinolfi et al, 2007) and work performance are affected by bothersome urinary symptoms in $78 \%$ of cases and pain is seen in 80\% (Irani et al, 1999; Joshi et al, 2003). Overall QoL is impaired in $45 \%$ to $80 \%$ of patients with a ureteral stent.

The pathophysiology of stent-related symptoms remains unclear. However, the pain and LUTS caused by stent placement has been attributed to lower ureter and bladder spasm due to local irritation of the stent (Thomas R, 1993).Thomas reported that an important factor of stent-related symptoms is the pressure transmitted to the renal pelvis during urination and trigonal irritation by the intravesicular part of the stent (Thomas, 1993). For this reason, several attempts to minimize stent-related symptoms have recently been reported. To minimize stent morbidity some groups postulated that stent length and position must be adequate (Ho et al, 2008). Others suggested that alpha 1 -blockers and anticholinergics would be effective (Damiano et al, 2008; Norris et al, 2008) while some tried intravesical instillation of chemical agents (Beiko et al, 2004) or periureteral injection of botulinum toxin (Gupta et al, 2010).

Wang et al believed that pharmacologic management is simpler and less invasive than other ways in improving the lower urinary tract symptoms of patients with indwelling double-J ureteral stents. Systemic 
review and metaanalysis conducted by Yakoubi et al in 2011 showed that alpha- blockers were found to be associated with a significant decrease in urinary symptoms, pain and in general health, however, they were not associated with a benefit in work or sexual matters.

Tamsulosin acts as a selective inhibitor of alpha-1a/1d mediated contraction of the smooth muscles in distal ureter, bladder trigone, and bladder neck (Shibasaki et al, 1992). It is thought that relaxing these smooth muscles decreases bladder outlet resistance and voiding pressure, with beneficial effect on stent related LUTS (Wang et al, 2009; Choo et al, 2008; Lee et al, 2013; Kuyumcuoglu et al, 2012). Wang et al. in 2009 found that tamsulosin can improve a subset of stent-related urinary symptoms and quality of life effectively and may be applied in routine clinical practice. Similarly Huang also found tamsulosin is better in improving a subset of stent-related urinary symptoms, pain, voiding flank pain and quality of life in comparison with placebo (Huang et al. 2009). Solifenacin is a muscarinic receptor antagonist used for treatment of patients with overactive bladder (OAB) (Vardy et al, 2009; Ho et al, 2010) and might be effective as well for stent related symptoms (Choo et al, 2008; Lee et al, 2013; Kuyumcuoglu et al, 2012).

Lee et al 2013 conducted a comparative study between solifenacin and placebo and found that solifenacin alone had significantly lesser total symptom score, urgency and urge incontinence scores. As for stent-related body pain, solifenacin group had significantly less flank, abdominal, urethral pain and hematuria $(\mathrm{p}<0.05)$. The solifenacin versus control group showed significant benefits in lower urinary tract symptoms, stent-related pain and hematuria in both genders $(\mathrm{p}<0.05)$. Four subjects encountered minor adverse events and one had urinary retention in solifenacin group. For patients undergoing Ureterorenoscopy lithotripsy and indwelling double-J stent, postoperative solifenacin use was effective and well-tolerated for the treatment of lower urinary tract symptoms, stent-related body pain and hematuria irrespective of genders.

Lim et al in 2011, in nonrandomized and retrospective study found that combination therapy with tamsulosin and solifenacin improved both irritative and obstructive symptoms more than solifenacin when used alone. Randomized clinical trial conducted by Shalaby et al in 2013, found statistically significant differences in total IPSS, QoL score, and OAB-q score in patient receiving both tamsulosin and solifenacin as compared to patients receiving solifenacin alone. In contrast, prospective randomized study conducted by Lee et al found no statistical differences between combination of tamsulosin and tolterodine when compared with placebo and tamsulosin alone and they concluded that correct stent positioning and verification of its location were more important than medication for lessening stent-related storage symptoms. There are conflicting results in literatures regarding optimization of stent related problems (Shalabyet al in 2013) Hence, this study was carried out to find the efficacy and safety of combination of Tamsulosin with Solifenacin and Tamsulosin alone in relieving the LUTS related to DJ stent, so that it may help us in guiding the future treatment plan for stent related problems at BPKIHS.

\section{Material And Methods}

A randomized, parallel group clinical trial was carried out at BPKIHS for the stone diseases (Nephrolithiasis, Ureterolithiasis) in the urinary system that had undergone endoscopic surgery as PCNL or URS or open surgery as Pyelolithotomy or Ureterolithotomy followed by DJ stenting. Patients were randomized into two groups, group 1 - patients received tamsulosin and solifenacin both whereas group 2 - patients received tamsulosin only. For this purpose altogether 70 patients were enrolled, 35 in each group. Ethical clearance was taken from the Institutional Ethical review Board of the BP Koirala institute of health sciences (IERB).

\section{Inclusion Criteria}

Patients $\geq 18$ years of age with unilateral double-J ureteral stent who have agreed for random allocation of treatment will be enrolled in the study.

\section{Exclusion Criteria}

1. Age less than 18 years

2. Allergic to drugs

3. Pregnant women

4. Bilateral stents

5. Patients who are using analgesics before surgery.

6. Refusal of consent

\section{Sample Size Calculation}

Based on the result studied by Shalaby et al (2013), IPSS total score before insertion of stent and 2 weeks after insertion in tamsulosin group as $8.91 \pm 4.26$ and $12.40 \pm 4.50$ and in combination group $8.92 \pm 4.12$ and 
$8.48 \pm 4.22$, a total of 35 patients are needed in each group with mean difference between tamsulosin and combination group as $3.93, \mathrm{SD} \pm 4.27$ effect size $0.6711, \alpha$ error $5 \%$, power $80 \%$ and 2 sided.

\section{Randomization And Allocation Concealment}

Permuted block design of randomization was utilized with allocation ratio of 1:1 and a block size of 4 was created using www.randomization.com. A sequentially generated number with the treatment group was written in a sealed envelope. Each patient was assigned a patient identity number and allocated to receive treatment with combination of Tamsulosin and Solifenacin or Tamsulosin alone depending upon the specification in the sealed envelope.

\section{Clinical Care, Follow Up And Outcome Measures}

Patients were selected among those who had undergone retrograde double-J ureteral stent placement, following ureterorenoscopy (URS), ureterolithotomy, and percutaneous nephrolithotomy (PCNL) for urolithiasis. The ureteral stent was composed of polyurethane material with diameter of 6 Fr. and the lengths was $24 \mathrm{~cm}$ and $26 \mathrm{~cm}$. depending on the patient's height. A detailed history with respect to the chief complains, duration of illness, associated symptoms, and progression of disease was taken. A thorough clinical examination was done. All relevant investigations- complete blood count, serum urea, creatinine, Prothrombin time and international normalized ratio, serology (hepatitis B and C, HIV), Urine routine and microscopic examination and culture and sensitivity, Ultrasonography of kidney, ureter and bladder, intravenous urography, X-ray KUB were done. After all the preoperative preparation, informed written and understood consent, patients were posted for surgery.

Surgery was performed under anesthesia (general or spinal) and the position of the stent was confirmed by fluoroscopy. The stents were removed after 2 weeks of surgery unless indicated for long time stenting as ureteric injury, stricture or perforation. The patients were divided into two groups. Group 1 was provided with combination of Tamsulosin with Solifenacin (Urimax $0.4 \mathrm{mg}$ and Bispec 10mg Dr. reddy PH Lt) once a day and Group 2 with Tamsulosin (Urimax $0.4 \mathrm{mg}$ cipla PH Lt) once a day till the removal of stent. Patients completed written International Prostate Symptom Score/ quality of life (IPSS/QoL) and Visual Analogue Pain Scale graded as 1-10 (pain score of 1-2 was regarded as mild pain, 3-5 as moderate pain 6-8 as severe pain and 9-10 as worst pain), before the insertion, before the discharge (2nd or 3rd postoperative day) and 2 weeks after the insertion of stent. The IPSS was divided into the total score, voiding symptom score, and storage symptom score, and each one was compared. Urine for routine and microscopic examination and culture and sensitivity were sent on 3rd postoperative day or before the discharge of patient and sexual discomfort was assessed after 2 weeks of stent insertion.

\section{Results}

A randomized, parallel group clinical trial was carried out at BPKIHS for the stone diseases (Nephrolithiasis, Ureterolithiasis) in the urinary system who had undergone endoscopic surgery as PCNL or URS or open surgery as Pyelolithotomy or Ureterolithotomy followed by DJ stenting. Patients were randomized into two groups, group 1 - patients received tamsulosin and solifenacin both whereas group 2 - patients received tamsulosin only. This study was carried out to find out the efficacy and safety of the drugs in improving the DJ stent related lower urinary tract symptoms between the groups. For this purpose altogether 70 patients were enrolled, 35 in each group.

Socio demographic and risk factor were presented as follows:

\section{Consort flow diagram}

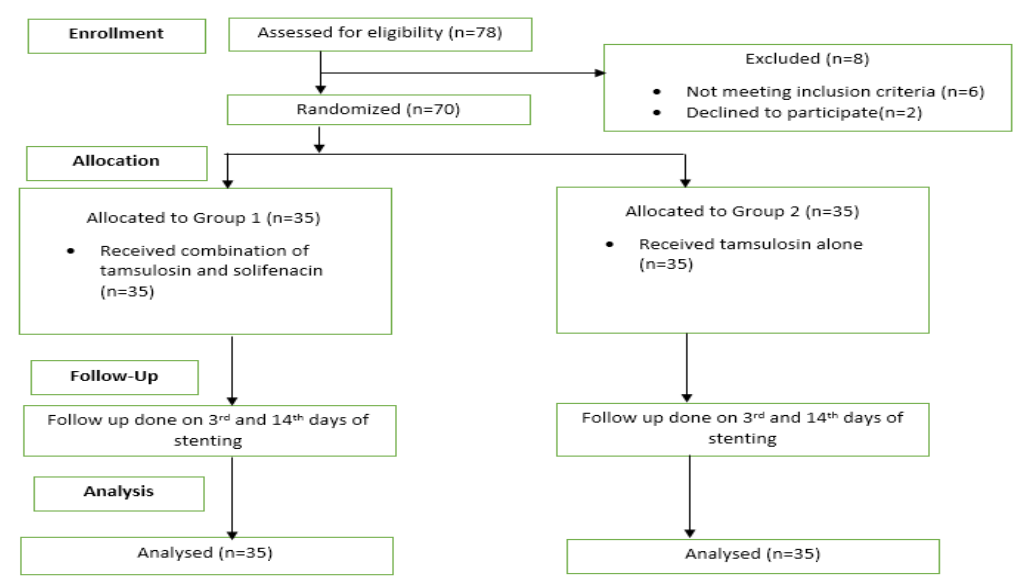


Efficacy And Safety Of Combination Of Tamsulosin With Solifenacin And Tamsulosin Alone In ...

\section{Age distribution}

\begin{tabular}{|c|c|c|c|}
\hline Age gr in years & $\begin{array}{c}\text { Group 1 (Tamsulosin and } \\
\text { solifenacin combination } \\
(\mathbf{n = 3 5})\end{array}$ & $\begin{array}{c}\text { Group 2 (Tamsulosin } \\
\text { only) } \\
(\mathbf{n = 3 5})\end{array}$ & $\begin{array}{c}\text { Total } \\
(\mathbf{n = 7 0})\end{array}$ \\
\hline$<29$ & $12(63.2 \%)$ & $7(36.8 \%)$ & $19(27.1 \%)$ \\
\hline $30-39$ & $11(37.9 \%)$ & $18(62.1 \%)$ & $29(41.4 \%)$ \\
\hline $40-49$ & $5(62.5 \%)$ & $3(37.5 \%)$ & $8(11.4 \%)$ \\
\hline $50-59$ & $6(66.7 \%)$ & $3(33.3 \%)$ & $9(12.9 \%)$ \\
\hline$>60$ & $1(20.0 \%)$ & $4(80.0 \%)$ & $5(7.2 \%)$ \\
\hline Total & $35(50.0 \%)$ & $35(50.0 \%)$ & $70(100.0 \%)$ \\
\hline
\end{tabular}

3. Baseline characteristics of the patients $(n=70)$

\begin{tabular}{|c|c|c|c|c|}
\hline & $\begin{array}{l}\text { Group 1(Tamsulosin and } \\
\text { solifenacin combination } \\
\qquad(n=35)\end{array}$ & $\begin{array}{c}\text { Group } \\
\text { 2(Tamsulosin } \\
\text { only) } \\
(\mathrm{n}=35) \\
\end{array}$ & $\begin{array}{c}\text { T-test - * } \\
\text { Persons chi-square test- } * * \\
\text { Fisher's Exact Test - **** } \\
\text { Mann-Whitney Test- } * * * *\end{array}$ & p value \\
\hline $\begin{array}{l}\text { Mean age in years } \pm \\
\text { SD }\end{array}$ & $35.71 \pm 12.53$ & $38.77 \pm 13.14$ & $0.996^{*}$ & 0.323 \\
\hline $\begin{array}{l}\text { Gender } \\
\text { Female } \\
\text { Male } \\
\end{array}$ & $\begin{array}{l}18(41.9 \%) \\
17(63.0 \%) \\
\end{array}$ & $\begin{array}{l}25(58.1 \%) \\
10(37.0 \%) \\
\end{array}$ & $2.954 * *$ & 0.086 \\
\hline $\begin{array}{l}\text { Frequency } \\
\text { Yes } \\
\text { No }\end{array}$ & $\begin{array}{l}17(44.7 \%) \\
18(56.3 \%)\end{array}$ & $\begin{array}{l}21(55.3 \%) \\
14(43.8 \%) \\
\end{array}$ & $0.921 * *$ & 0.337 \\
\hline $\begin{array}{l}\text { Nocturia } \\
\text { Yes } \\
\text { No }\end{array}$ & $\begin{array}{l}12(50.0 \%) \\
23(50.0 \%) \\
\end{array}$ & $\begin{array}{l}12(50.0 \%) \\
23(50.0 \%) \\
\end{array}$ & $0.000 * *$ & 1.00 \\
\hline $\begin{array}{l}\text { Intermittency } \\
\text { Yes } \\
\text { No }\end{array}$ & $\begin{array}{l}2(100.0 \%) \\
33(48.5 \%)\end{array}$ & $\begin{array}{c}0(00.0 \%) \\
35(51.5 \%)\end{array}$ & $0.246^{* * * *}$ & 0.493 \\
\hline $\begin{array}{l}\text { Incomplete emptying } \\
\text { Yes } \\
\text { No }\end{array}$ & $\begin{array}{c}7(70.0 \%) \\
28(46.7 \%) \\
\end{array}$ & $\begin{array}{c}3(30.0 \%) \\
32(53.3 \%) \\
\end{array}$ & $1.867 * *$ & 0.172 \\
\hline $\begin{array}{l}\text { Poor stream } \\
\text { Yes } \\
\text { No }\end{array}$ & $\begin{array}{c}5(50.0 \%) \\
30(50.0 \%)\end{array}$ & $\begin{array}{c}5(50.0 \%) \\
30(50.0 \%)\end{array}$ & $0.000 * *$ & 1.00 \\
\hline $\begin{array}{l}\text { Straining } \\
\text { Yes } \\
\text { No }\end{array}$ & $\begin{array}{c}5(83.3 \%) \\
30(46.9 \%)\end{array}$ & $\begin{array}{c}1(16.7 \%) \\
34(53.1 \%)\end{array}$ & $0.099 * * *$ & 0.198 \\
\hline $\begin{array}{l}\text { Urgency } \\
\text { Yes } \\
\text { No } \\
\end{array}$ & $\begin{array}{c}3(75.0 \%) \\
32(48.5 \%)\end{array}$ & $\begin{array}{c}1(25.0 \%) \\
34(51.5 \%)\end{array}$ & $0.307 * * *$ & 0.614 \\
\hline $\begin{array}{l}\text { Co-morbidities } \\
\text { Diabetes } \\
\text { Hypertension } \\
\text { CoPD } \\
\end{array}$ & $\begin{array}{l}1(50.0 \%) \\
6(50.0 \%) \\
1(50.0 \%) \\
\end{array}$ & $\begin{array}{l}1(50.0 \%) \\
6(50.0 \%) \\
1(50.0 \%)\end{array}$ & $0.000 * *$ & 1.00 \\
\hline $\begin{array}{l}\text { Stent Placement } \\
\text { URSL } \\
\text { PCNL } \\
\text { Ureterolithotomy }\end{array}$ & $\begin{array}{l}18(54.5 \%) \\
15(45.5 \%) \\
2(50.0 \%) \\
\end{array}$ & $\begin{array}{l}15(45.5 \%) \\
18(54.5 \%) \\
2(50.0 \%) \\
\end{array}$ & $0.545 * *$ & 0.761 \\
\hline $\begin{array}{l}\text { Baseline scoring } \\
\text { IPSS } \\
\text { QoL } \\
\text { VAPS }\end{array}$ & $\begin{array}{l}7.63 \pm 4.22 \\
1.31 \pm 1.49 \\
6.03 \pm 1.75\end{array}$ & $\begin{array}{l}5.63 \pm 5.64 \\
2.31 \pm 0.96 \\
5.83 \pm 1.75\end{array}$ & $\begin{array}{c}\text { ***** } \\
471 * * * * \\
482 * * * * \\
586 * * * *\end{array}$ & $\begin{array}{l}0.940 \\
0.511 \\
0.752\end{array}$ \\
\hline
\end{tabular}

4. Growth of organism $(n=70)$ 


\section{Growth of organism}

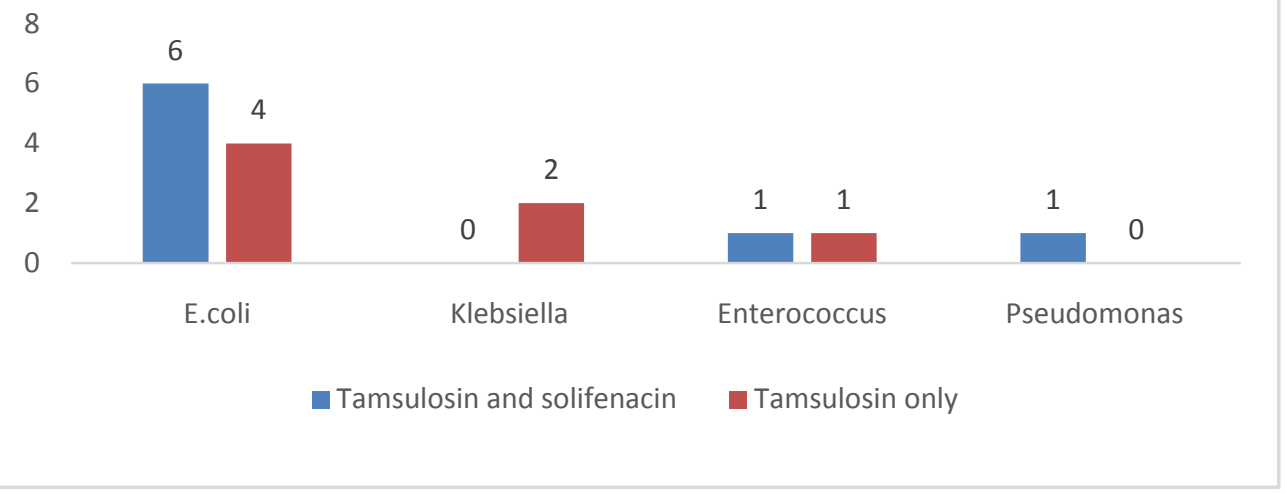

5. Days of hospitalization. $(n=70)$

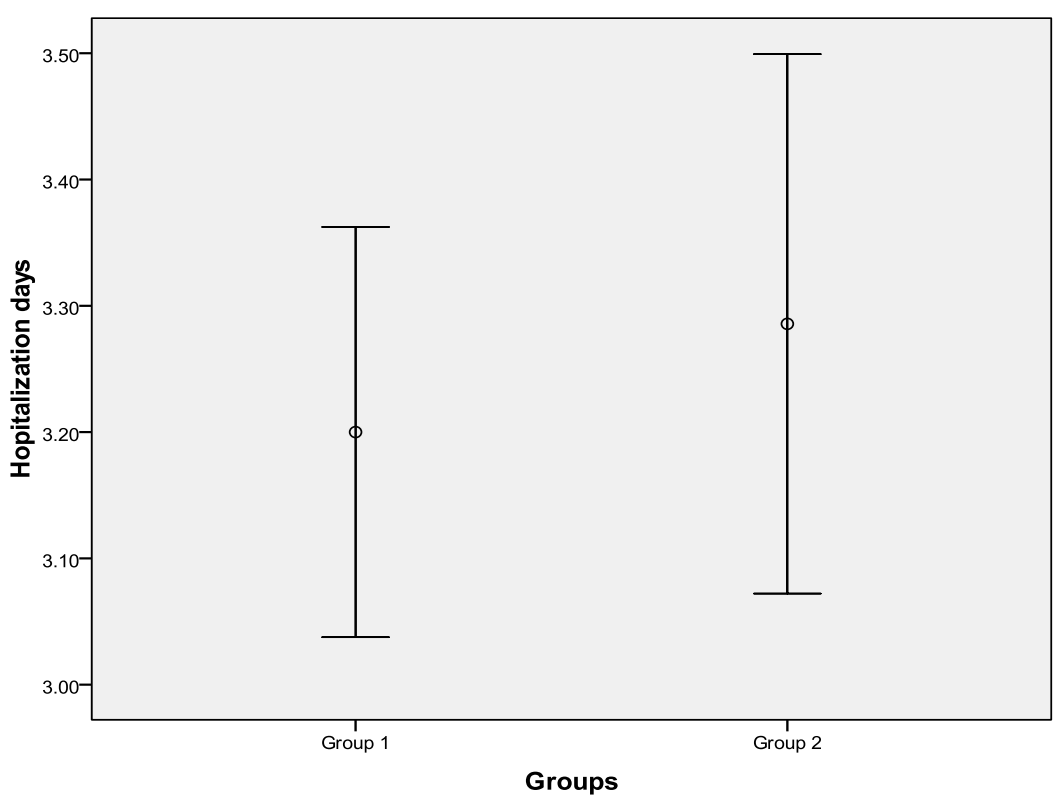

6. Sexual discomfort $(\mathrm{n}=70)$

\begin{tabular}{|c|c|c|c|c|c|c|}
\hline $\begin{array}{c}\text { Sexual } \\
\text { discomfort }\end{array}$ & $\begin{array}{c}\text { Group } \\
\text { 1(Tamsulosin } \\
\text { and } \\
\text { solifenacincom } \\
\text { bination } \\
(\mathrm{n}=35) \\
\end{array}$ & $\begin{array}{l}\text { Group } \\
\text { 2(Tamsulos } \\
\text { in only) } \\
(\mathrm{n}=35)\end{array}$ & Total & $\begin{array}{c}\text { Persons } \\
\text { Chi- } \\
\text { Square test } \\
\text { value }\end{array}$ & & Remarks \\
\hline Yes & $4(15.4 \%)$ & $22(84.6 \%)$ & $\begin{array}{c}26 \\
(37.1 \% \\
)\end{array}$ & \multirow{2}{*}{19.825} & \multirow{2}{*}{$<0.001$} & \multirow{2}{*}{$\begin{array}{c}\text { Significan } \\
\mathrm{t}\end{array}$} \\
\hline No & $31(70.5 \%)$ & $13(29.5 \%)$ & $\begin{array}{c}44 \\
(62.9 \% \\
)\end{array}$ & & & \\
\hline
\end{tabular}

7. International prostatic symptoms scoring of patients $(n=70)$

\begin{tabular}{|c|c|c|c|c|c|}
\hline \multirow[b]{2}{*}{ IPSS Score } & \multicolumn{2}{|c|}{ Mean \pm SD (Median, IQR) } & \multirow[b]{2}{*}{$\begin{array}{c}\text { Mann-Whitney } \\
\text { Test value }\end{array}$} & \multirow[b]{2}{*}{$\begin{array}{c}\mathbf{p} \\
\text { value }\end{array}$} & \multirow[b]{2}{*}{ Remarks } \\
\hline & $\begin{array}{c}\text { Group } \\
\text { 1(Tamsulosin and } \\
\text { solifenacin } \\
\text { combination } \\
(\mathrm{n}=35) \\
\end{array}$ & $\begin{array}{c}\text { Group } \\
\text { 2(Tamsulosin only) } \\
(\mathrm{n}=35)\end{array}$ & & & \\
\hline Before insertion & $7.63 \pm 4.22(7,4-10)$ & $5.63 \pm 5.64(6,0-9)$ & 471 & 0.940 & $\begin{array}{c}\text { Not } \\
\text { significant }\end{array}$ \\
\hline $3^{\text {rd }}$ day of stenting & $4.57 \pm 2.36(4,3-6)$ & $4.37 \pm 2.39(4,3-6)$ & 588 & 0.771 & $\begin{array}{c}\text { Not } \\
\text { significant }\end{array}$ \\
\hline
\end{tabular}


Efficacy And Safety Of Combination Of Tamsulosin With Solifenacin And Tamsulosin Alone In ...

\begin{tabular}{|c|c|c|c|c|c|}
\hline $\begin{array}{l}2 \text { weeks after } \\
\text { stenting }\end{array}$ & $0.57 \pm 1.42(1,0-2)$ & $1.63 \pm 1.68(2,0-3)$ & 378 & 0.002 & Significant \\
\hline $\begin{array}{l}\text { Friedman test }(\mathrm{P} \\
\text { value })\end{array}$ & $66.13(<0.001)$ & $22.14(<0.001)$ & & & Significant \\
\hline
\end{tabular}

8. Quality of life symptoms scoring of patients. $(n=70)$

\begin{tabular}{|c|c|c|c|c|c|}
\hline \multirow[b]{2}{*}{ Qol Score } & \multicolumn{2}{|c|}{ Mean \pm SD (Median, IQR) } & \multirow[b]{2}{*}{$\begin{array}{c}\text { Mann- } \\
\text { Whitney Test }\end{array}$} & \multirow[b]{2}{*}{ p value } & \multirow[b]{2}{*}{ Remarks } \\
\hline & $\begin{array}{l}\text { Group 1(Tamsulosin } \\
\text { and solifenacin } \\
\text { combination } \\
(n=35)\end{array}$ & $\begin{array}{c}\text { Group } \\
\text { 2(Tamsulosin } \\
\text { only) } \\
(n=35) \\
\end{array}$ & & & \\
\hline Before insertion & $\begin{array}{c}1.31 \pm 1.49 \\
(1,0-2)\end{array}$ & $\begin{array}{c}2.31 \pm 0.96 \\
(3,3-4) \\
\end{array}$ & 482 & 0.511 & $\begin{array}{c}\text { Not } \\
\text { significant }\end{array}$ \\
\hline $\begin{array}{l}3^{\text {rd }} \text { day of } \\
\text { stenting }\end{array}$ & $\begin{array}{c}0.20 \pm 0.58 \\
(0,0-0)\end{array}$ & $\begin{array}{c}1.66 \pm 1.18 \\
(2,0-3)\end{array}$ & 209 & $<0.001$ & Significant \\
\hline $\begin{array}{l}2 \text { weeks after } \\
\text { stenting }\end{array}$ & $\begin{array}{c}0.03 \pm 0.16 \\
(0,0-0) \\
\end{array}$ & $\begin{array}{c}0.80 \pm 0.79 \\
(1,0-1) \\
\end{array}$ & 276 & $<0.001$ & Significant \\
\hline $\begin{array}{l}\text { Friedman test (P } \\
\text { value) }\end{array}$ & $26.06(<0.001)$ & $59.36 \quad(<0.001)$ & & & Significant \\
\hline
\end{tabular}

9. Visual analogue pain scale scoring of patients. $(n=70)$

\begin{tabular}{|c|c|c|c|c|c|}
\hline \multirow[b]{2}{*}{ VAPS Score } & \multicolumn{2}{|c|}{ Mean \pm SD (Median, IQR) } & \multirow[b]{2}{*}{$\begin{array}{c}\text { Mann- } \\
\text { Whitney Test }\end{array}$} & \multirow[b]{2}{*}{ p value } & \multirow[b]{2}{*}{ Remarks } \\
\hline & $\begin{array}{c}\text { Group } \\
\text { 1(Tamsulosin and } \\
\text { solifenacin } \\
\text { combination } \\
(\mathrm{n}=35)\end{array}$ & $\begin{array}{c}\text { Group 2(Tamsulosin } \\
\text { only) } \\
(\mathrm{n}=35)\end{array}$ & & & \\
\hline $\begin{array}{l}\text { Before } \\
\text { insertion }\end{array}$ & $\begin{array}{c}6.03 \pm 1.75 \\
(6,5-7)\end{array}$ & $\begin{array}{c}5.83 \pm 1.75 \\
(6,4-7)\end{array}$ & 586 & 0.752 & $\begin{array}{c}\text { Not } \\
\text { significant }\end{array}$ \\
\hline $\begin{array}{l}3^{\text {rd }} \text { day of } \\
\text { stenting }\end{array}$ & $\begin{array}{c}2.37 \pm 1.61 \\
(2,1-4) \\
\end{array}$ & $\begin{array}{c}2.43 \pm 1.75 \\
(2,1-4)\end{array}$ & 604 & 0.924 & $\begin{array}{c}\text { Not } \\
\text { significant }\end{array}$ \\
\hline $\begin{array}{l}2 \text { weeks after } \\
\text { stenting }\end{array}$ & $\begin{array}{c}0.06 \pm 0.23 \\
(0,0-0)\end{array}$ & $\begin{array}{c}1.14 \pm 1.26 \\
(1,0-2)\end{array}$ & 317 & $<0.001$ & Significant \\
\hline $\begin{array}{l}\text { Friedman test } \\
\text { (P value) }\end{array}$ & $64.62(<0.001)$ & $62.21 \quad(<0.001)$ & & & Significant \\
\hline
\end{tabular}

10. Adverse effects

Adverse drug reaction was not present in any study population.

\section{Discussion}

Ureteral stents, which were introduced by Zimskind et al in 1967, are widely used for urinary tract disease (Zimskind, Fetter and Wilkerson, 1967. The double-J stents are common tools and integral part used in endourologic practices. Double-J stents play a major role in a wide range of situations to prevent or to relieve ureteral obstruction (Shalaby et al in 2013). Despite the usefulness of double-J stent, some of the patients might encounter stent-related morbidities such as urinary tract infection (UTI), lower urinary tract symptoms (LUTS), stent-related body pain and hematuria.

In previous literatures, various medical therapy and proper positioning of the stent have been studied to minimize these stent related problems. A randomized clinical trial conducted by Shalaby et al in 2013, found statistically significant differences in total IPSS, QoL score, and OAB-q score in patient receiving both tamsulosin and solifenacin as compared to patients receiving solifenacin alone. In contrast, prospective randomized study conducted by Lee et al in $\mathbf{2 0 1 0}$ found no statistical differences between combination of tamsulosin and tolterodine when compared with placebo and tamsulosin alone and they concluded that correct stent positioning and verification of its location were more important than medication for lessening stent-related storage symptoms.

There are conflicting opinions in literatures regarding optimization of stent related problems. Hence, a randomized, parallel group clinical trial was carried out at BPKIHS to find out the efficacy and safety between the two groups: group 1 - patients were given tamsulosin and solifenacin both whereas group 2- patients were given tamsulosin only. Total 70 patients were enrolled in this study, 35 in each group.

\section{Age characteristics}

Most of the patients $(29,41.4 \%)$ in this study were aged between 30-39 years. The mean age with SD in group 1 was $35.71 \pm 12.53$ years and in group 2 was $38.77 \pm 13.14$ years with p value of 0.323 . This is similar to the study conducted by Shalaby et al in 2013, in which mean age of patients was $41.3 \pm 17.1$ years in the patients receiving tamsulosin alone whereas the patients receiving tamsulosin and solifenacinboth, mean age was $43.6 \pm 17.6$ years. . 
This may be because urolithiasis is common in middle age group of people.

\section{Gender characteristics}

In our study mean of male to female ratio was 1:1.06 in group 1 and 1:2.5 in group 2 .

This is in contrast to the study conducted by Shalaby et al in 2013, in which male to female ratio of 2:1 was found in the patient receiving tamsulosin alone whereas the patients receiving tamsulosin and solifenacin both, male to female ratio was 2.2:1. Similar study conducted by Lim et al in $\mathbf{2 0 1 1}$ had with male to female ratio 1.26: 1 in the group patient receiving tamsulosin alone and 2.2:1 in the patient receiving combination of tamsulosin and solifenacin both .

The female predominance may be due to the fact that in developing country like Nepal females still use to drink less water to avoid multiple voiding especially during outdoor activities. To some extent overall higher female population in demography of Nepal may be a contributing factor.

\section{Indication of stent characteristics}

Indications for stent placement in both the groups were found similar: URSL (51.42\%), PCNL (42.85\%) \&Ureterolithotomy $(5.73 \%)$ in group $1 ;$ and URSL (42.85\%), PCNL(51.42\%) \&Ureterolithotomy(5.73\%) in group 2 respectively. In the study by Shalaby et al in 2013, had most of the patient enrolled in the study had undergone URS followed by ESWL and PCNL. The preference of endoscopic surgery over open surgery is increasing nowadays. ESWL was not considered in our study as we don't have this facility in our institute.

\section{Urine examination characteristics}

Urine examination for microscopic red blood cells (RBC) done after 2 weeks of DJ stenting demonstrates microscopic RBC in most of the patients irrespective of the groups.

Similarly urine routine and microscopic examination for white blood cells (WBC) done 2 weeks after the stent placement demonstrated WBC in most of the patients irrespective of the groups.

These findings may be due to stent-related trivial trauma.

\section{Urine culture characteristics}

Fifteen out of 70 (21.4\%) patients were found to be culture positive at 2 weeks of stenting and the most common organism isolated was E.coli, followed by Klebsiella, Enterococcus and Psedomonas.

Most of the culture positive patients were sensitive to imipenem 11 (73.3\%) followed by amikacin 10 (66.7\%).

\section{Days of hospitalization characteristics}

Mean days of hospital admission in group 1 was 3.20 with SD \pm of 0.472 and in group 2 was 3.28 with SD \pm of 0.621 .

\section{Sexual discomfort characteristics}

Sexual discomfort was found in 4 (15.4\%) patients in group 1 and 22 (84.6\%) patients in group 2.

Less sexual discomfort in group 1 may be due to additional effects of Solifenacin as it acts on M1, M2 and M3 muscarinic receptors which get irritated due to the movement of the lower end of the stent.

\section{International prostatic symptoms scoring characteristics}

IPSS scores before insertion of stent, on 3rd day of stenting and 2 weeks of stenting in group 1 were $7.63 \pm 4.22,4.57 \pm 2.36,0.57 \pm 1.42$ and in group 2 were $5.63 \pm 5.64,4.37 \pm 2.39,1.63 \pm 1.68$ respectively and $p$ value was significant only after 2 weeks of stenting. So there is significant reduction in IPSS score at 2 weeks after stenting in group 1 compared to group 2. In the study byLim et al in 2011, total IPSS scores of the patient on tamsulosin alone before insertion of stent, on the day of stent insertion and on the day of stent removal were $8.60 \pm 4.12,12.53 \pm 4.79$ and $12.77 \pm 5.24$ respectively while those in patients receiving combination of tamsulosin and solifenacin were $8.72 \pm 4.16,11.47 \pm 3.98$ and $7.16 \pm 3.37$ respectively with significant $p$ value of 0.001 on the day of stent removal. In the similar study by Shalaby et al in 2013, total IPSS scores before the insertion of stent and after 2 weeks of stent insertion in the patients receiving tamsulosin alone were $8.91 \pm 4.26$ and $12.40 \pm 4.50$ and in patients receivingoftamsulosin and solifenacin were $8.92 \pm 4.12$ and $.48 \pm 4.12$ respectively and found to be statistically significant after 2 weeks of stent insertion ( $\mathrm{p}$ value 0.001 ).

\section{Quality of life symptoms scoring characteristics}

Qol scores before insertion of stent, on 3rd day of stenting and 2 weeks after stenting in group 1 were $1.31 \pm 1.49,0.20 \pm 0.58$, and $0.03 \pm 0.16$ respectively and those in group 2 were $2.31 \pm 0.96,1.66 \pm 1.18$ and $0.80 \pm 0.79$ respectively with significant $\mathrm{p}$-value on 3 rd day and 2 weeks after stenting. 
In the study by Shalaby et al in 2013, quality of life scores before the stent placement and 2 weeks after the stent placement in the patients receiving tamsulosin alone were $1.78 \pm 1.70$ and $2.80 \pm 1.52$ and those in the patients receiving combination of tamsulosin and solifenacin were $1.77 \pm 1.44$ and $1.88 \pm 1.22$ respectively with significant p-value of 0.001 after 2 weeks of stent placement. In another study by Lim et al in 2011 quality of life scores before insertion, on the day of stent placement and on the day of stent removal in the patients receiving tamsulosin alone were $2.19 \pm 1.80,2.44 \pm 1.71$ and $3.07 \pm 1.67$ respectively; and those in the patients receiving combination of tamsulosin and solifenacin were $1.88 \pm 1.77,2.34 \pm 1.56$ and $1.47 \pm 1.44$ respectively with significant p-value on the day of stent removal.

\section{Visual analogue pain scale scoring characteristics}

VAPS scores before insertion of stent, on 3rd day of stenting and 2 weeks after stenting in the group 1 were $6.03 \pm 1.75,2.37 \pm 1.61$, and $0.06 \pm 0.23$ respectively and those in group 2 were $5.83 \pm 1.75,2.43 \pm 1.75$ and $1.14 \pm 1.26$ respectively with significant $P$ value after 2 weeks of stent placement. In study byLim et al in 2011 VAPS preoperatively, on the day of insertion and on the day of stent removal in the patient with tamsulosin alone were $6.60 \pm 1.59,2.88 \pm 1.50,3.67 \pm 1.94$ respectively while in the other group receiveingtamsulosin and solifenacin both the scores preoperatively, on the day of insertion and on the day of stent removal were $6.28 \pm 1.65,2.44 \pm 1.37$ and $2.69 \pm 1.31$ respectively.

Similar study by Shalaby et al in 2013, found VAPS before insertion and 2 weeks after insertion in the patients receiving tamsulosin alone to be $2.55 \pm 1.84$ and $3.23 \pm 1.23$ respectively whereas those in patients receiving tamsulosin and solifenacin both were $2.22 \pm 1.27$ and $2.69 \pm 1.41$ respectively. The p-value was significant after 2 weeks of insertion of stent.

\section{Conclusion}

The combination of Tamsulosin and Solifenacin significantly reduced DJ-stent related LUTS, improves quality of life following DJ stenting, decreased the pain and reduced sexual discomfort in comparision to Tamsulosin alone. There were no significant difference in incidence of hematuria, urinary tract infection and hospital stay observed between the groups. Adverse drug reaction was not present in any study population. This study had a few limitations like short term follow up, small population size and single centre study.

\section{Recommendation}

The combination of Tamsulosin and Solifenacin should be considered for stent related symptoms. However, further large scale, multicentric trials are required to compare the effectiveness of combination of different alfa-blockers and anti-muscarinic agents in order to optimize the medical therapy for the treatment of DJ-stent related symptoms.

\section{References}

[1]. BEIKO, D. T., WATTERSON, J. D., KNUDSEN, B. E., NOTT, L., PAUTLER, S. E., BROCK, G. B., RAZVI, H. \& DENSTEDT, J. D. (2004) Double-blind randomized controlled trial assessing the safety and efficacy of intravesical agents for ureteral stent symptoms after extracorporeal shockwave lithotripsy. J Endourol, 18, 723-30.

[2]. CHEW, B. H., KNUDSEN, B. E. \& DENSTEDT, J. D. (2004) The use of stents in contemporary urology. Curr Opin Urol, 14, 1115 .

[3]. CHOO, M. S., LEE, J. Z., LEE, J. B., KIM, Y. H., JUNG, H. C., LEE, K. S., KIM, J. C., SEO, J. T., PAICK, J. S., KIM, H. J., NA, Y. G. \& LEE, J. G. (2008) Efficacy and safety of solifenacin succinate in Korean patients with overactive bladder: a randomised, prospective, double-blind, multicentre study. Int J Clin Pract, 62, 1675-83.

[4]. DAMIANO, R., AUTORINO, R., DE SIO, M., GIACOBBE, A., PALUMBO, I. M. \& D'ARMIENTO, M. (2008) Effect of tamsulosin in preventing ureteral stent-related morbidity: a prospective study. J Endourol, 22, 651-6.

[5]. DENSTEDT, J. D., WOLLIN, T. A., SOFER, M., NOTT, L., WEIR, M. \& RJ, D. A. H. 2001. A prospective randomized controlled trial comparing nonstented versus stented ureteroscopic lithotripsy. J Urol, 165, 1419-22.

[6]. GUPTA, M., PATEL, T., XAVIER, K., MARUFFO, F., LEHMAN, D., WALSH, R. \& LANDMAN, J. (2010) Prospective randomized evaluation of periureteral botulinum toxin type A injection for ureteral stent pain reduction. J Urol, 183, 598-602.

[7]. HO, C. H., CHANG, T. C., LIN, H. H., LIU, S. P., HUANG, K. H. \& YU, H. J. (2010) Solifenacin and tolterodine are equally effective in the treatment of overactive bladder symptoms. J Formos Med Assoc, 109, 702-8.

[8]. HO, C. H., CHEN, S. C., CHUNG, S. D., LEE, Y. J., CHEN, J., YU, H. J. \& HUANG, K. H. (2008) Determining the appropriate length of a double-pigtail ureteral stent by both stent configurations and related symptoms. J Endourol, 22, 1427-31.

[9]. HUANG SW, CHANG CH. (2009) "Effects of specific alpha-1A/1D blocker on lower urinary tract symptoms due to double-J stent: a prospectively randomized study," Urol Res, 37, 147-152.

[10]. IRANI, J., SIQUIER, J., PIRES, C., LEFEBVRE, O., DORE, B. \& AUBERT, J. (1999) Symptom characteristics and the development of tolerance with time in patients with indwelling double-pigtail ureteric stents. BJU Int, 84, $276-9$.

[11]. JEONG, H., KWAK, C. \& LEE, S. E. (2004) Ureteric stenting after ureteroscopy for ureteric stones: a prospective randomized study assessing symptoms and complications. BJU Int, 93, 1032-4; discussion 1034-5.

[12]. JOSHI, H. B., NEWNS, N., STAINTHORPE, A., MACDONAGH, R. P., KEELEY, F. X., JR. \& TIMONEY, A. G. (2003) Ureteral stent symptom questionnaire: development and validation of a multidimensional quality of life measure. $J$ Urol, 169, $1060-4$.

[13]. JOSHI, H. B., STAINTHORPE, A., KEELEY, F. X., JR., MACDONAGH, R. \& TIMONEY, A. G. (2001) Indwelling ureteral stents: evaluation of quality of life to aid outcome analysis. J Endourol, 15, 151-4. 
[14]. KUYUMCUOGLU, U., ERYILDIRIM, B., TUNCER, M., FAYDACI, G., TARHAN, F. \& OZGUL, A. (2012) Effectiveness of medical treatment in overcoming the ureteral double-J stent related symptoms. Can Urol Assoc J, 6, E234-7.

[15]. LEE, Y. J., HUANG, K. H., YANG, H. J., CHANG, H. C., CHEN, J. \& YANG, T. K. (2013) Solifenacin improves double-J stentrelated symptoms in both genders following uncomplicated ureteroscopic lithotripsy. Urolithiasis, 41, 247-52.

[16]. LIM, K. T., KIM, Y. T., LEE, T. Y. \& PARK, S. Y. (2011) Effects of tamsulosin, solifenacin, and combination therapy for the treatment of ureteral stent related discomforts. Korean J Urol, 52, 485-8.

[17]. NORRIS, R. D., SUR, R. L., SPRINGHART, W. P., MARGUET, C. G., MATHIAS, B. J., PIETROW, P. K., ALBALA, D. M. \& PREMINGER, G. M. (2008) A prospective, randomized, double-blinded placebo-controlled comparison of extended release oxybutynin versus phenazopyridine for the management of postoperative ureteral stent discomfort. Urology, 71, 792-5.

[18]. HALABY, E., AHMED, A. F., MAAROUF, A., YAHIA, I., ALI, M. \& GHOBISH, A. (2013) Randomized controlled trial to compare the safety and efficacy of tamsulosin, solifenacin, and combination of both in treatment of double-j stent-related lower urinary symptoms. Adv Urol, 2013, 752382.

[19]. SHIBASAKI, M., SUDOH, K., INAGAKI, O., UCHIDA, W. \& HONDA, K. (1992) Effect of the optical isomers of YM-12617 on increased intra-urethral pressure induced by phenylephrine in anaesthetized dogs. J Auton Pharmacol, 12, 263-8.

[20]. SIGHINOLFI, M. C., MICALI, S., DE STEFANI, S., MOFFERDIN, A., GRANDE, M., GIACOMETTI, M., FERRARI, N., RIVALTA, M. \& BIANCHI, G. (2007) Indwelling ureteral stents and sexual health: a prospective, multivariate analysis. J Urol, $178,229-31$

[21]. THOMAS, R. (1993) Indwelling ureteral stents: impact of material and shape on patient comfort. J Endourol, 7, 137-40.

[22]. VARDY, M. D., MITCHESON, H. D., SAMUELS, T. A., WEGENKE, J. D., FORERO-SCHWANHAEUSER, S., MARSHALL, T. S. \& HE, W. (2009) Effects of solifenacin on overactive bladder symptoms, symptom bother and other patient-reported outcomes: results from VIBRANT - a double-blind, placebo-controlled trial. Int J Clin Pract, 63, 1702-14.

[23]. WANG, C. J., HUANG, S. W. \& CHANG, C. H. (2009) Effects of specific alpha-1A/1D blocker on lower urinary tract symptoms due to double-J stent: a prospectively randomized study. Urol Res, 37, 147-52.

[24]. YAKOUBI, R., LEMDANI, M., MONGA, M., VILLERS, A. \& KOENIG, P. (2011) Is there a role for alpha-blockers in ureteral stent related symptoms? A systematic review and meta-analysis. J Urol, 186, 928-34.

[25]. ZIMSKIND, P. D., FETTER, T. R. \& WILKERSON, J. L. (1967) Clinical use of long-term indwelling silicone rubber ureteral splints inserted cystoscopically. J Urol, 97, 840-4. 